\title{
Urticaceae Juss. do Parque Estadual das Fontes do Ipiranga, São Paulo, SP, Brasil
}

\author{
Sergio Romaniuc Neto ${ }^{1,2}$, André Luiz Gaglioti ${ }^{1}$ e Bárbara Melissa de Oliveira Guido ${ }^{1}$
}

Recebido: 03.07.2008; aceito: 19.03.2009

ABSTRACT - (Urticaceae Juss. of the "Parque Estadual das Fontes do Ipiranga", São Paulo, SP, Brazil). Urticaceae is represented by seven genera and 14 species in the "Parque Estadual das Fontes do Ipiranga" of which 11 species are natives and 3 cultivated (Pilea cadierei Gagnep. \& Guillaumin, Pilea nummulariifolia (Sw.) Wedd. e Boehmeria nivea Jacq.). The genera Cecropia is included with 3 species and Coussapoa with only one species.

Key words: Atlantic Forest, taxonomy, urtics

RESUMO - (Urticaceae Juss. do Parque Estadual das Fontes do Ipiranga, São Paulo, SP, Brasil). Urticaceae está representada por sete gêneros e 14 espécies na área do Parque. Destas, 11 são nativas e três cultivadas (Pilea cadierei Gagnep. \& Guillaumin, Pilea nummulariifolia (Sw.) Wedd. e Boehmeria nivea Jacq.). Foram incluídos os gêneros Cecropia com três espécies e Coussapoa com uma espécie.

Palavras-chave: Floresta Atlântica, taxonomia, urticáceas

\section{Introdução}

A sistemática das espécies de Urticaceae apresenta atualmente numerosas dificuldades, como constatado pelos artigos publicados recentemente. Desde Weddell (1856), que foi quem descreveu as Urticaceae da forma mais completa, até Cronquist (1988) a circunscrição desta família não apresentou grandes variações taxonômicas. Somente a partir de recentes estudos sobre a filogenia do grupo (Sytsma et al. 2002, APG II 2003) é que a circunscrição de Urticaceae foi ampliada com a inclusão, nesta família, dos gêneros tradicionalmente reconhecidos em Cecropiaceae Berg. Segundo Sytsma et al. (2002), Urticaceae é um grupo monofilético e circunscrita de modo amplo, incluindo espécies herbáceas a lenhosas com cistólitos mais ou menos alongados, laticíferos restritos à casca ou muito reduzidos e produzindo seiva translúcida e mucilaginosa, gineceu pseudomonômero com óvulos basais, estames curvos e embriões retos.

Embora autores como Berg (1978), Berg \& Rosselli (2005), Judd et al. (1994) e Romaniuc Neto (1993, 1999) discutam a posição sistemática dos gêneros de Cecropiaceae Berg, ou mesmo a validade e posição filogenética desta família (Berg \& Carauta
1996, Judd et al. 1999, Romaniuc Neto 1999, APG II 2003), seguimos para a flora do PEFI, o conceito atual de Sytsma et al. (2002), considerando Cecropia e Coussapoa em Urticaceae.

No Estado de São Paulo a família é pouco conhecida, sendo Urticaceae recentemente estudada por Romaniuc Neto $(1992,1993)$ para a Ilha do Cardoso e PEFI respectivamente. Neste último foram tratados somente os táxons Cecropia e Coussapoa em Cecropiaceae Berg. Hoehne et al. (1941) realizou o primeiro estudo sobre as Urticaceae do PEFI citando três espécies para a família, excetuando Cecropia e Coussapoa que tradicionalmente estavam incluídas em Moraceae.

O presente estudo complementa o trabalho realizado por Romaniuc Neto (1993), que tratou os gêneros Cecropia e Coussapoa dentro de Cecropiaceae, que é parte do levantamento florístico da flora fanerogâmica da Reserva do Parque Estadual das Fontes do Ipiranga (PEFI) proposto por Melhem et al. (1981). Novas ocorrências de Cecropia para o PEFI e a aceitação da recente circunscrição de Urticaceae (Sytsma et al. 2002, Judd et al. 2009), justificam a inclusão das espécies já tratadas por Romaniuc Neto (1993), no presente estudo para o PEFI.

1. Instituto de Botânica, Seção de Curadoria do Herbário, Caixa Postal 3005, 01061-970 São Paulo, SP, Brasil

2. Autor para correspondência: sromaniuc@uol.com.br 


\section{Material e métodos}

O Parque Estadual das Fontes do Ipiranga -

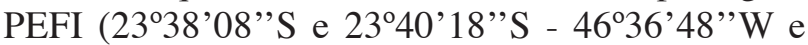
$46^{\circ} 38^{\prime} 00^{\prime}$ 'W) está situado no município de São Paulo, a cerca de 10,2 km sul e 0,8 km leste do centro da cidade (Melhem et al. 1981), com área total de 549,31 ha e altitude média de $798 \mathrm{~m}$ (Bicudo et al. 2002). O Instituto de Botânica é responsável por 164,45 ha da área total, que são subdivididos em reserva biológica - 116 ha, área com as instalações administrativas e seções técnicas do Instituto - 11,94 ha e área de visitação pública do Jardim Botânico - 36,30 ha (Rocha \& Cavalheiro 2001). A reserva biológica, embora esteja sob forte pressão urbana da região metropolitana de São Paulo, possui remanescentes da vegetação nativa e pode ser caracterizada como sendo uma extensão da floresta ombrófila densa com influência da floresta estacional semidecidual.

Os materiais botânicos examinados encontram-se depositados no Herbário SP, do Instituto de Botânica, e as coletas complementares foram realizadas de acordo com as técnicas propostas em Fidalgo \& Bononi (1984). Os dados sobre o planejamento da flora do PEFI, foram apresentados em Melhem et al. (1981) e Milanez et al. (1990), complementados em Barros et al. (2002).

\section{Resultados e Discussão}

Urticaceae inclui no PEFI sete gêneros e 14 espécies, representando cerca de $60 \%$ das espécies ocorrentes no Estado de São Paulo. Destas, Boehmeria nivea Jacq. e Pilea cadierei Gagnep. \& Guillaumin são cultivadas, originárias da China e Vietnã respectivamente. Pilea nummulariifolia (Sw.) Wedd., considerada ornamental, é cultivada nas áreas ajardinadas do Jardim Botânico e tem sua distribuição natural desde a Malásia até o nordeste da América do Sul.

No presente estudo, são tratadas as espécies nativas de Boehmeria, Laportea, Phenax, Pilea e
Urera, incluindo Cecropia e Coussapoa que foram estudados anteriormente por Romaniuc Neto (1993).

\section{Urticaceae Juss.}

Árvores, arbustos, subarbustos ou ervas, monóicos ou dióicos, terrestres ou hemiepifíticos (Coussapoa), glabros ou pubescentes, às vezes com indumento de tricomas urticantes nos ramos e folhas (Urera e Laportea); laticíferos restritos à casca ou ausentes; gemas caulinares protegidas por estípulas terminais. Folhas alternas ou opostas; lâmina simples, inteira ou palmatilobada, glabra ou pubescente; margem inteira, dentada, crenada ou serreada; cistólitos puntiformes ou fusiformes; nervação actinódroma; estípulas terminais ou axilares, livres ou conadas, caducas ou persistentes. Inflorescências axilares cimosas ou racemosas em panículas, espigas, capítulos ou glomérulos; flores diclinas, actinomorfas, aclamídeas (Phenax) ou monoclamídeas; (2-)3-5 lobadas, lóbulos livres ou conados; (1-)3-5 estames, às vezes com pistilódio, filetes dobrados ou retos no botão, anteras rimosas, ovais ou globosas, deiscência explosiva; ovário súpero, 2-carpelar, 1-locular, 1-óvulo por lóculo, placentação basal, estilete indiviso, estigma filiforme, penicilado, peltado ou comoso. Drupas ou aquênios secos ou com perianto carnoso, acrescente na maturação. Semente 1, globosa, elíptica ou oval, geralmente com endosperma; embrião reto; cotilédones membranáceos ou carnosos.

Urticaceae apresenta distribuição cosmopolita, incluindo cerca de 50 gêneros e 1200 espécies. No Brasil ocorrem 12 gêneros e cerca de 80 espécies. Cecropia tem maior destaque na flora brasileira por ser típico de formações secundárias ou clareiras no interior de florestas, difere dos outros gêneros da família por possuir folhas palmatilobadas e inflorescências protegidas por espata. Boehmeria e Urera são característicos de áreas abertas como pastagens, este último, reconhecido por apresentar tricomas urticantes.

Chave para identificação dos gêneros de Urticaceae ocorrentes no Parque Estadual Fontes do Ipiranga

1. Plantas com indumento de tricomas urticantes

2. Ervas monóicas; filetes curvos no botão; estigmas filiformes subterminais Laportea

2. Arbustos dióicos; filetes retos no botão; estigmas penicilados terminais Urera

1. Plantas com indumento de tricomas não urticantes

3. Lâminas palmatilobadas, incisões dos lobos radiais Cecropia

3. Lâminas inteiras

4. Árvores ou arbustos, dióicos, geralmente hemiepifíticos quando jovens, freqüientemente estrangulantes posteriormente. 
4. Arbustos, subarbustos ou ervas, monóicos

5. Folhas opostas; flores pistiladas 3-lobadas; estigmas penicilados Pilea

5. Folhas alternas, (sub)opostas ou opostas; flores pistiladas 2-4-lobadas ou aclamídeas; estigmas filiformes

6. Folhas (sub)opostas, comumente opostas, espiraladas até dísticas; inflorescências em espigas; flores pistiladas com perianto tubular Boehmeria

6. Folhas alternas; inflorescências em glomérulos; flores pistiladas aclamídeas Phenax

\section{Boehmeria Jacq.}

Arbustos monóicos, glabros ou pubescentes; tricomas simples, não urticantes. Folhas (sub)opostas, espiraladas até dísticas; lâminas inteiras, lisas ou rugosas, cartáceas ou membranáceas; estípulas axilares, livres ou conadas na base. Inflorescências espigas; brácteas presentes; flores sésseis ou (sub) sésseis; flores estaminadas esverdeadas, perianto 4-lobado; lóbulos conados na base; prefloração valvar; estames 4, livres; pistilódio presente com ovário rudimentar alargado, glabro ou com tricomas simples na base; flores pistiladas 4-lobadas; estigma filiforme. Aquênios membranáceos envoltos pelo perianto que se torna coriáceo na maturação. Sementes elípticas ou ovais, testa membranácea; endosperma escasso, cotilédones ovais ou elípticos.

De acordo com Berg (1992), Boehmeria inclui cerca de 60-80 espécies, com distribuição pantropical, estendendo-se para regiões temperadas. Na região neotropical apresenta cerca de 8-10 espécies (Killip 1960). Embora o gênero possua espécies dióicas, como em Boehmeria caudata Sw., no PEFI foram encontradas apenas 2 espécies monóicas: Boehmeria cylindrica (L.) Sw. e Boehmeria nivea (L.) Gaudich., destas apenas a primeira é nativa do Parque.

Boehmeria cylindrica (L.) Sw., Prodr.: 34. $178820 \equiv$ Urtica cylindrica L., Sp.pl. 2: 984. 1753.

Figura 1a

Arbustos 0,8-1,5 m alt. Ramos jovens 2-3 mm diâm., lisos a estriados, entrenós $2-5 \mathrm{~cm}$ de compr. Lâminas 2-8(-9) × 1-3,5 cm, ovais a elípticas, pubérulas em ambas as faces; ápice agudo a (sub) acuminado; base obtusa; margem crenada-dentada; nervação actinódroma, 3 nervuras basais, 3-4 nervuras secundárias; cistólitos puntiformes presentes; manchas alvas próximo às nervuras; pecíolos $0,5-3 \mathrm{~cm}$ de compr., pubérulos; estípulas 2-5 mm, lanceoladas, pubérulas, tricomas castanhos. Inflorescências 2,5-8(12) $\mathrm{cm}$ compr., axilares ou distribuídas ao longo dos ramos jovens, espigas reduzidas 2-3(-5) mm compr., reunidas ao longo dos ramos, sésseis; brácteas 0,5-1,2 mm compr., elípticas, castanhas, pubérulas, caducas; flores estaminadas 1-1,5 mm diâm.; lóbulos 1,5-1,8 mm compr., gibosos, pubérulos; estames curvos no botão, retos após deiscência explosiva, anteras alvas; flores pistiladas 1-1,2 mm diâm., pubérulas; perianto tubular, lóbulos conados na base; estilete 0,1-0,2mm, curvo ou reto, glabro na metade inferior. Aquênios 1-1,2 mm diâm., elípticos, castanho-esverdeados. Sementes 0,8-1 mm diâm., pubérulas, tricomas uncinados.

Material examinado: 8-I-1965, fl. $\widehat{O}$, G. Eiten \& W.D. Cleyton 5791 (SP).

Material adicional examinado: BRASIL. São Paulo: São Paulo, 17-I-1996, fl. ㅇ, R. Simão-Bianchini et al. 865 (SP).

Distribuição geográfica: Espécie de ampla distribuição nas Américas, ocorrendo desde o Canadá até a Argentina. No Brasil habita áreas de florestas e campos, principalmente nos estados costeiros do Nordeste e Sudeste, adentrando-se para o interior a partir de Minas Gerais até o Mato Grosso.

Boehmeria cylindrica pode ser reconhecida no PEFI pelas folhas com cistólitos puntiformes e manchas alvas. A inflorescência possui frequentemente rebrotas foliares no ápice. Por ser comum em locais abertos como clareiras e beira da mata sua coleta no PEFI foi negligenciada, existindo somente uma única referencia até o momento, datada de 1965. Ainda, ocorre no PEFI Boehmeria nivea (L.) Gaudich, cultivada e originária da Ásia, popularmente conhecida como "rami", é reconhecida pelo longo pecíolo com até $20 \mathrm{~cm}$ compr. e indumento tomentoso de tricomas alvos recobrindo toda a planta.

\section{Cecropia Loefl.}

Árvores dióicas; laticíferos restritos à casca, látex translúcido; tronco e ramos jovens fistulosos, glabros, pubescentes ou tomentosos-velutinos. Folhas peltadas, 
palmatilobadas; nervação actinódroma suprabasal, palminérvias quando jovens e radial quando adultas; pecíolo freqüentemente com triquílio na base; estípula 1, não amplexicaule, vinácea, alva ou creme-esverdeada. Inflorescências axilares em espigas, pêndulas, geralmente aos pares, freqüentemente estipitadas, protegidas por uma espata decídua que as envolve completamente na antese; flores estaminadas 2-3-lobadas, perianto tubular, espesso no ápice, glabro ou pubescente; estames 2-(3), filetes desiguais, anteras extrorsas; flores pistiladas com perianto delgado, pubescente na porção apical, indumento de tricomas aracnóideos, alvos; estigma penicilado a peltado. Aquênios com perianto acrescido e carnoso na maturação; endosperma presente.
Cecropia apresenta cerca de 61 espécies (Berg \& Rosselli 2005), com distribuição pantropical e muitas espécies de regiões montanhosas andinas da Bolívia até a Venezuela. Possui características morfológicas que o permitem ser facilmente reconhecido, como espatas cobrindo integralmente as partes florais das inflorescências até a antese e a presença freqüente de triquílio (corpúsculos de Müller) na base do pecíolo. São árvores pioneiras de clareiras ou beiras de mata, que vivem preferencialmente nas partes úmidas ou semi-úmidas da região Neotropical. A maioria das espécies é mirmecófila.

No PEFI ocorrem três espécies: $C$. glaziovii Snethl., C. hololeuca Miq. e C. pachystachya Trécul.

Chave para identificação de espécies de Cecropia ocorrentes no Parque Estadual das Fontes do Ipiranga

1. Ramos, folhas e estípulas densamente tomentosos-velutinos; estipulas alvas ou creme-esverdeadas externamente e ferrugíneas internamente; espatas muito reduzidas, não envolvendo os amentos; 2-3 amentos pistilados; triquílios ausentes na base do pecíolo C. hololeuca

1. Ramos, folhas e estípulas glabros ou pubérulos; estípulas pardo-avermelhadas ou esverdeadas externamente e vináceas ou amareladas internamente; espata envolvendo os amentos; 5-7 amentos pistilados; triquílios presentes na base do pecíolo

2. Estípulas avermelhadas e pubérulas externamente, indumento aracnóideo esparso; flores estaminadas pubescentes; flores pistiladas com indumento aracnóideo não atingindo o ápice do perianto; estigma comoso; anteras 0,8-2 mm compr. C. glaziovii

2. Estípulas esverdeadas e pubescentes externamente, indumento aracnóide denso; flores estaminadas glabras; flores pistiladas com indumento aracnóideo cobrindo o ápice do perianto; estigma peltado; anteras $0,5-0,7 \mathrm{~mm}$ compr. C. pachystachya

Cecropia glaziovii Snethl., Notizbl. Bot. Gart. Berlin 8(75): 358. 1923.

\section{Figura $1 \mathrm{~b}$}

Nome vulgar: embaúba-vermelha

Árvores 8-10 m alt., geralmente com raízes adventícias escoras. Ramos glabros ou pubescentes. Lâminas 40-50 cm diâm. quando adultas, incisões 1/3 a 1/2 do centro, 9-10 lobadas, lobos com ápice arredondado a obtuso ou raramente acuminado, cartáceas a sub-coriáceas; face adaxial pubérula, indumento de tricomas simples, estrigosos, uncinados e indumento aracnóideo esparso, concentrados na margem; face abaxial pubescente, indumento de tricomas estrigosos na lâmina e aracnóideos nas nervuras; nervuras secundárias 10 -15 pares na parte livre do segmento mediano, retas, às vezes dicotômicas próximo às margens; pecíolos 55-80 cm compr., pubescentes, indumento de tricomas unicelulares uncinados; estípulas $12-18 \times 4-10 \mathrm{~cm}$, glabras ou pubérulas, pardo-avermelhadas externamente e vináceas na face interna. Inflorescências isoladas ou aos pares; espatas 7-20 × 4-8 cm, seríceo-tomentosas e castanho-ferrugíneas externamente, glabras e vináceas internamente; pedúnculos 3,5-11 cm compr., carnosos, vináceos com manchas alvo-esverdeadas; amentos estaminados 15-18, 12-23 cm compr., estipitados, esverdeados quando jovens e creme-amarelados a vináceos posteriormente, glabros; flores estaminadas 2-lobadas, pubescentes; amentos pistilados 5-7, 15$20 \mathrm{~cm}$ compr., sésseis ou (sub)estipitados, vermelhos a vináceos; flores pistiladas 3-4-lobadas, carnosas, tricomas aracnóideos circundando o ápice do estilete, não chegando a cobrir o estigma comoso. Aquênios elipsóides a ovais. Sementes oblongas a ovais, testa lisa; cotilédones adpressos, embrião reto. 
Material examinado: 22-IX-1931, fl. ̊̂, F. C. Hoehne (SP 282068A); 22-IX-1931, fl. †, F. C. Hoehne (SP 282068B); 10-XI-1944, fl. O, W. Hoehne (SP113635); 2-IX-1949, fl. 犬̂, W. Hoehne \& M. Kuhlmann (SP12788); 2-IX-1949, fl. Ô, W. Hoehne \& M. Kuhlmann (SP12783); 2-IX-1949, fl. O, W. Hoehne \& M. Kuhlmann 3325 (SP); 10-XI-1944, fl. + , W. Hoehne (SP113635); 7-VI-1988, fl. O, S. Romaniuc Neto 760 (SP).

Distribuição geográfica: Ocorre na faixa leste do Brasil, da Bahia ao Rio Grande do Sul adentrando-se até Goiás e Mato Grosso. Prefere áreas de floresta úmida, sendo comum em florestas secundárias, em altitude até $1.300 \mathrm{~m}$.

As estípulas apicais, nervuras das folhas e espatas das inflorescências são caracteristicamente de coloração vináceo-avermelhada. É observada a presença de formigas do gênero Azteca no interior do caule. Esta espécie se diferencia das demais, principalmente por apresentar estípulas avermelhadas a vináceas e folhas com esparso ou sem indumento aracnóideo. No PEFI ocorre nos pontos mais elevados e locais mais preservados do interior da reserva. É possível ainda observar um exemplar na área ajardinada do Jardim Botânico denominada “arboreto". Segundo a classificação de Berg \& Carauta (1996), C. glaziovii está na categoria de conservação - Baixo Risco (LR).

Cecropia hololeuca Miq. in Mart., Fl. bras. 4(1): 148. 1853.

\section{Figura $1 \mathrm{c}-\mathrm{d}$}

Nome vulgar: embaúba-branca

Árvores 9-12 m alt., raramente com raízes adventícias escoras. Ramos densamente tomentosovelutinos. Lâminas 40-70 cm diâm. quando adultas, incisões $1 / 4$ a 1/6 do centro, 8-10 lobadas, lobos com ápice arredondado a agudo, freqüentemente acuminado, cartáceas; faces adaxial e abaxial densamente tomentoso-vilosas em toda a extensão; tricomas aracnóideos; parte livre dos lobos com 1215 pares de nervuras secundárias, arqueadas próximo às margens; pecíolos 40-90 cm compr., tomentosos, tricomas aracnóideos, alvos; estípulas 10-40 × 5-20 $\mathrm{cm}$, alvas ou creme-esverdeadas, seríceo-tomentosas a vilosas, densos tricomas aracnóideos. Inflorescências aos pares; espatas reduzidas a uma bráctea filiforme, não envolvendo os amentos, 1,5-6 × 0,5-1 cm; pedúnculos 5-17 cm compr., glabros ou pubescentes, carnosos, vermelho-escuros; amentos estaminados
9-13, 6-10 cm compr., não estipitados, vináceos a negros, glabros; flores estaminadas 2-3-lobadas, glabras. Inflorescências pistiladas com 1-2 espigas, 9-15 cm compr., estipitadas ou raramente sésseis, esverdeadas quando jovens e purpúreas a negras na maturação; flores pistiladas 2-4-lobadas, carnosas, tricomas aracnóideos concentrados no ápice dos lóbulos, estigma penicilado. Aquênios elipsóides a oblongos, nuculados. Sementes elípticas, testa rugosa.

Material examinado: 10-XI-1944, estéril, F.C. Hoehne (SP28270); 22-V-1945, fl. ㅇ, M. Kuhlmann \& E. Kuhn. 3327 (SP); 7-VI-1988, fl. ㅇ, S. Romaniuc Neto 761 (SP).

Material adicional examinado: BRASIL. São Paulo: São Luiz do Paraitinga, 21-V-1993, fl. Ô, S. Romaniuc Neto 1382 (SP).

Distribuição geográfica: Característica da costa leste do Brasil adentrando-se até Minas Gerais e Mato Grosso. Característica das áreas preservadas da Floresta Ombrófila Densa, em regiões montanhosas e lugares íngremes com altitude até $1.400 \mathrm{~m}$.

Esta espécie é facilmente reconhecida pelo indumento tomentoso-velutino e alvo que recobre todas as partes vegetativas da planta e por não apresentar triquilho na base do pecíolo.

Cecropia pachystachya Trécul, Ann. Sci. Nat. (Paris), sér. 3, 8: 80. 1847.

Figura 1e

Nome vulgar: embaúba-branca

Árvores 5-8 m alt., raramente com raízes adventícias escoras. Ramos pubescentes. Lâminas $20-40 \mathrm{~cm}$ diâm. quando adultas, incisões $3 / 4$ a 9/10 do centro, 8-11 lobadas, lobos com ápice arredondado a agudo ou acuminado, cartáceas; face adaxial pubérula, indumento de tricomas simples, estrigosos, uncinados, concentrados nas nervuras principal e secundárias, indumento aracnóideos alvos, concentrados na margem; face abaxial tomentosa em toda a extensão do limbo, indumento de tricomas aracnóideos; nervuras secundárias 10-13(-15) pares na parte livre do segmento mediano, arqueadas próximo às margens; pecíolos 30-80,0 cm compr., tomentosos, indumento de tricomas aracnóideos alvos; estípulas 8-20 $\times 3-10 \mathrm{~cm}$, creme-esverdeadas e tomentosas externamente, ferrugíneo-esverdeadas e pubérulas na face interna. Inflorescências aos pares; espatas 6-12× 2-4 cm, tomentosas e alvo-esverdeadas externamente, glabras e castanho-escuras internamente; pedúnculos 
4-14 cm compr., carnosos, esverdeado, glabros ou pubescentes; amentos estaminados 4-12, 6-12 cm compr., estipitados, creme-amarelados quando jovens e castanho-esverdeados posteriormente, glabros; flores estaminadas com perianto tubular, glabro; amentos pistilados 4-7, 6-15 cm compr., estipitados, creme-esverdeados; flores pistiladas 2-3- lobadas, (sub)carnosas, tricomas aracnóideos circundando o ápice do estilete, chegando a cobrir o estigma peltado. Aquênios elipsóides a oblongos. Sementes elípticas, testa rugosa.

Material examinado: 15-I-1988, fl. 오, S. Romaniuc Neto 787 (SP); 12-VI-1995, fl. Ô, S. Romaniuc Neto 1512 (SP).

Distribuição geográfica: Espécie de ampla distribuição no Brasil, desde o limite sul da Bacia Amazônica, até a região central e leste do país, estendendo-se até o Paraguai e norte da Argentina. Ocorre em áreas florestadas, desde a restinga até o cerrado, incluindo as regiões da caatinga, em altitudes até $1.100 \mathrm{~m}$.

Espécie característica de bordas de mata, formações abertas e áreas sob impacto antrópico. No PEFI ocorre nas áreas de clareiras e bordas das áreas florestadas da reserva. As estípulas apicais, nervuras das folhas e espatas das inflorescências são caracteristicamente de coloração creme-esverdeada, por vezes pode-se encontrar alguns indivíduos apresentando estípulas apicais avermelhadas quando jovens. É observada a presença de formigas do gênero Azteca no interior do caule que são menos agressivas do que aquelas presentes em C. glaziovii. Berg \& Carauta (1996) e Berg \& Rosselli (2005) divergem sobre a circunscrição desta espécie, os primeiros propõem um complexo de 3 espécies e 2 variedades para este táxon, cuja separação baseia-se principalmente na coloração e indumento das estípulas apicais, enquanto Berg \& Rosseli consideram apenas uma única espécie para $C$. pachystachya. Nos espécimes estudados para o PEFI, os caracteres citados por Berg \& Carauta (1996) não permitiram a separação em taxa distintos, portanto foi considerado para esta flora $C$. pachystachya Trécul, sensu stricto. Segundo a classificação de Carauta et al. (1996), C. pachystachya está na categoria de conservação - Baixo Risco (LR).

\section{Coussapoa Aubl.}

Hemiepífitas (ou epífitas) ou terrestres, árvores ou arbustos com raízes aéreas ou raízes escoras; lactíferos presentes, látex aquoso. Lâminas inteiras, em espiral, nervação pinada ou trinervada, margem inteira à subcrenada; estípulas fusionadas, amplexicaules, geralmente deixando cicatrizes oblíquas. Inflorescências frequentemente aos pares na axila das folhas, ramificadas ou nas pistiladas geralmente não ramificadas com brácteas interflorais; flores em capítulos globosos, elipsóides ou clavados, livres ou nas pistiladas algumas vezes conadas; flores estaminadas (2-)3(-4) lobadas, perianto tubular, glabros ou pubescente; estames 2-3 filetes desiguais, anteras extrorsas; flores pistiladas com perianto tubular; estigma penicilado à subpeltado. Aquênios indeiscentes; endosperma presente.

Coussapoa possui cerca de 47 espécies distribuídas em florestas tropicais úmidas da América do Sul e Central.

Coussapoa microcarpa (Schott.) Rizzini, Dusenia 1(5): 295.1950.

Figura $1 \mathrm{f}-\mathrm{h}$

Nome vulgar: mata-pau

Árvores ou arbustos 2-12(-15) m alt., hemi-epifíticos quando jovem, freqüentemente estrangulantes. Ramos glabros ou pubérulos, indumento de tricomas aracnóideos alvos, amarelos ou castanhos. Lâminas (2-)6-10(-14) × 2-5 cm, coriáceas, elípticas a oblongas; ápice agudo a obtuso; base aguda a obtusa; margem levemente revoluta próximo à base; face adaxial glabra; face abaxial glabra ou pubérula principalmente nas nervuras; nervação acródoma basal, 3 nervuras irradiantes da base do limbo, 6-12 pares de nervuras secundárias; pecíolos 1-3(-4,0) cm compr., glabros; estípulas 2, amplexicaules, 1,5$3(-4,5) \times 5-1 \mathrm{~cm}$ larg., pubescentes, indumento de tricomas subseríceos a hirsutos, alvo-amarelados ou castanhos, na face externa, glabras na face interna. Inflorescências estaminadas ramificadas, 5-9 capítulos globosos; pedúnculos 0,5-1,5 cm compr., freqüentemente fendido, pubescentes; flores (3-)4 lobadas, monoclamídeas, actinomorfas; lóbulos livres; estames completamente fundidos. Inflorescências pistilada não ramificada, 1(-4) capítulos, globosos; pedúnculos 1,5-4 cm compr., pubérulos; flores pistiladas, geralmente solitárias, perianto tubular ou clavado; estigma 1, penicilado, exserto. Infrutesência 0,5-1,5 cm diâm., pedúnculos 5-7 cm compr.Aquênios amarelos a alaranjadas quando maduros. Sementes elípticas a ovais, castanho escuras.

Material examinado: 22-VII-1993, fl. Ô, I. Cordeiro \& C. Vilela 1237 (SP); 26-III-1950, fl. +, O. Handro 172 
(SP); 4-IX-1933, fl. Ô, F.C. Hoehne s.n. (SP 30923); 6-IX-1950, fl. ㅇ. M. Kuhlmann 2837 (SP); 20-X-1948, fl. Ô, M. Kuhlmann \& E. Kühn 3323 (SP).

Distribuição geográfica: No Brasil ocorre desde o Espírito Santo até o Rio Grande do Sul, comum em vegetação de restinga e floresta ombrófila densa em altitudes até $1100 \mathrm{~m}$. São encontradas populações desta espécie nas áreas litorâneas da Bahia, Paraíba e Pernambuco.

No Parque é muito comum no interior da mata, sendo também encontrada sobre diversas espécies arbóreas na área do Jardim Botânico. As folhas coriáceas discolores, verdes a castanho-escuras e brilhantes na face adaxial, castanho-claras e opacas na face abaxial, contrastam com as inflorescências negras. Segundo a classificação de Carauta (1996), $C$. microcarpa está na categoria de conservação - Baixo Risco (LR).

\section{Laportea Gaudich.}

Ervas monóicas, tricomas urticantes presentes. Folhas alternas, espiraladas até dísticas; lâmina inteira, lisa ou rugosa, papirácea; estípulas conadas. Inflorescências axilares, paniculadas; flores diclinas dispostas em glomérulos laxos, pedunculados; flores estaminadas 4-5-lobadas; lóbulos conados na base; estames 4-5, filetes curvos no botão; pistilódio presente; flores pistiladas 4-lobadas; lóbulos desiguais; estigma filiforme subterminal, curvo. Aquênios ovais, comprimidos lateralmente, glabros, não inclusos no perianto, sésseis ou estipitados, geralmente em pedicelos alados. Sementes elípticas a ovais.

Laportea possui cerca de 23 espécies com distribuição pantropical. Na região neotropical está representado por 3 espécies. Para o Brasil, apenas Laportea aestuans é citada. Um tratamento para o gênero é apresentado por Chew $(1965,1969)$ onde revisou as espécies anteriormente consideradas em Fleurya por Miquel (1853).

Laportea aestuans (L.) Chew, Gard. Bull. Singapore 21: 200. 1965 =Urtica aestuans L., Sp.pl. 2: 1397. $1753 \equiv$ Fleurya aestuans (L.) Gaudich. ex Miq. in Mart., Fl. bras 4(1): 196. 1853.

Figura 1 i

Ervas 1,5-2 m alt. Ramos estriados, carnosos, 2-8 mm diâm.; indumento de tricomas urticantes concentrados nos ramos e margens das folhas. Lâminas (1,5-)6-12 × (1)4-6 cm, ovais, alternas, ambas as faces com tricoma urticante esparso; ápice acuminado; base rotunda a subcordada ou aguda; margem serreada-crenada a dentada; nervação actinódroma, 3 nervuras basais, 4-6 pares de nervuras secundárias; pecíolos (1-)4-7 cm compr.; estípulas 2-6 mm compr., esparsamente pubérulas, geralmente bífidas no ápice. Inflorescências 5-15 cm compr.; flores estaminadas 1-1,5 mm diâm., lóbulos 0,7-1,5 mm compr., 2-5 tricomas urticantes na porção apical; anteras alvas; pedicelos 0,5-1 mm compr.; flores pistiladas 1-2 mm diâm.; lóbulos 0,3-0,5 mm compr., 2-5 tricomas urticantes na porção dorsal; estigma $0,2-$ $0,3 \mathrm{~mm}$; pedicelo até $0,3-0,5 \mathrm{~mm}$ compr. Aquênios 1-2 mm diâm., assimétrico. Sementes 0,6-1 mm, castanho a pretas.

Material examinado: 15-II-1967, T. Sendulsky 650 (SP)

Material adicional examinado: BRASIL. São Paulo: Santos, 16-VI-1935, A. Gehrt s.n. (SP33430).

Distribuição geográfica: Espécie ruderal com distribuição pantropical.

Esta espécie é reconhecida pela presença de tricomas urticantes, folhas alternas conspicuamente dentadas, inflorescências eretas, longas, flores reunidas em panícula de glomérulos. No PEFI ocorre nas áreas ajardinadas do Jardim Botânico e em áreas semi-sombreadas na beira da mata.

\section{Phenax Wedd.}

Arbustos ou subarbustos monóicos, glabros ou pubescentes; tricomas simples, não urticantes. Folhas alternas, dísticas; lâminas inteiras, lisas ou rugosas, cartáceas; estípulas axilares, livres. Inflorescências em glomérulos; brácteas presentes; flores sésseis ou (sub) sésseis; flores estaminadas 4-lobadas; lóbulos conados; prefloração valvar; estames 4; pistilódio presente; ovário rudimentar cônico ou linear, pubescente, tricomas lanosos; flores pistiladas aclamídeas; estigma filiforme, persistente no fruto, glabro ou pubescente. Aquênios (sub)membranáceos ou tenuamente crustáceos. Sementes ovais; testa membranácea, albume conspícuo ou escasso; cotilédones ovais; radícula cônica.

Phenax inclui cerca de 12 espécies com distribuição na América tropical (Burger 1977; Berg 1992) sendo que algumas destas foram naturalizadas nas regiões trópicas da Ásia. O gênero é freqüentemente confundido com algumas espécies de Boehmeria e Pouzolzia, mas difere destas pelas flores pistiladas aclamídeas e grande quantidade de 
brácteas florais nas inflorescências. No PEFI ocorre apenas Phenax sonneratii (Poir.) Wedd.

Phenax sonneratii (Poir.) Wedd. in A. DC., Prodr. 16(1): 235(37). 186 = Parietaria sonneratii Poir. in Lam., Encycl. 5: 15. 1804.

Figuras $1 \mathrm{j}$

Subarbustos 1-3 m alt. Ramos estriados, 1-3 mm diâm., hirsutos, entrenós de 0,5-1,5(-4,5) cm compr. Lâminas (2-)5,5-11,5 × 3-5 cm, lanceoladas a ovais ou elípticas; ápice agudo, acuminado ou obtuso; base arredondada, cordada ou cuneada; margem crenadaserreada; nervação actinódroma, 3 nervuras basais, $2 \times 2(-3)$ pares de nervuras secundárias; glabras ou pubescentes, híspidas, lisas ou escabras; cistólitos puntiformes em ambas as faces; pecíolos 1,5-5(-7) cm compr., pubescentes; estípulas 5-8 mm compr., ovais, ápice acuminado, ferrugíneas, pubescentes, tricomas concentrados nas margens e nervuras. Glomérulos axilares, sésseis, 9-11 mm diâm; brácteas 1,2-2,5 mm compr., obovais ou suborbiculares, pubérulas, ferrugíneas, membranáceas, imbricadas; flores estaminadas 3-3,5 mm compr.; lóbulos 1-1,5 mm compr., convexos, largamente apiculados; filetes conados na base, dobrados no botão, deiscência explosiva na antese; flores pistiladas 1-1,5 mm compr., protegidas por brácteas conadas; estilete lateral, filiforme, 3-4 vezes mais longo que o ovário. Aquênios 1,5-2 mm, ovais, assimétricos, verrugosos, pubérulos. Sementes $0,7-1 \mathrm{~mm}$.

Material examinado: 15-II-1967, fl. ô, T. Sendulsky 652 (SP).

Material adicional examinado: BRASIL. São Paulo: Cunha, 12-XII-1996, fl. O, J.P. Souza et al. 808 (SP); Monte Alegre, 19-XII-1942, fl. Ô, M. Kuhlmann 198 (SP).

Distribuição geográfica: Espécie de ampla distribuição na América tropical, desde o México até a Argentina.

A circunscrição de Phenax sonneratii necessita de revisão. Os espécimes descritos para a América Central (Burger 1977) e Guiana Francesa (Berg 1992) possuem flores estaminadas com perigônio dobrado e diferem dos exemplares encontrados no Brasil e Argentina (Soraru 1972) sem esta característica.

No PEFI ocorre em locais abertos ou sombreados das bordas de matas, freqüentemente invade áreas ajardinadas.
Pilea Lindl.

Ervas monóicas, anuais ou perenes, glabras ou pubescentes; tricomas simples, não urticantes. Folhas opostas, freqüentemente desiguais em tamanho e forma; lâminas inteiras, lisas ou rugosas, cartáceas ou membranáceas; estípulas axilares, simples, liguladas. Inflorescências em cimeiras simples ou ramificadas; brácteas persistentes ou caducas; flores sésseis ou pedunculadas; prefloração valvar; flores estaminadas (2-)3-4-lobadas, lóbulos conados na base, côncavos; estames (3-)4; pistilódio presente, ovário rudimentar cônico ou oblongo; flores pistiladas 3-lobadas; lóbulos desiguais, conados na base, lóbulo central maior que os laterais; estigma penicilado, caduco, estaminódios presentes. Aquênios membranáceos, ovais ou orbiculares, assimétricos, estipitados. Sementes orbiculares, albúmen reduzido ou ausente; cotilédones achatados, ovais a arredondados; radícula cônica.

Pilea tem distribuição pantropical com cerca de 600 espécies (Monro 2001). Na região neotropical ocorrem mais de 300 espécies e pode ser reconhecida pelas folhas opostas e estípula simples e ligulada na axila foliar.

O gênero é citado como importante elemento na sucessão natural na ocupação de espaços presentes nas formações vegetais secundárias e clareiras.

No PEFI, Pilea microphylla é subespontânea, formando grandes populações tanto no interior e borda da mata, como em locais abertos e ajardinados ou ainda entre calçamentos e fendas de muros. Pilea cadieri e Pilea nummuralifolia são cultivadas nas áreas ajardinadas. $P$. cadieri é originária do Vietnã, invasora e freqüentemente cultivada como ornamental no Brasil. São ervas de 20-30 cm alt., folhas 4-8 cm compr, lisas, variegadas, de coloração verde-clara com manchas prateadas. P. nummularifolia possui ampla distribuição em toda a região tropical. Considerada invasora em decorrência da sua propagação agressiva em áreas naturais a partir dos locais onde é cultivada. São ervas de 10-15 cm alt., folhas 1-2 cm compr., rugosas, de coloração verde-escura, arredondadas e margem crenada.

Pilea microphylla (L.) Liebm., Kongel. Danske Vidensk. Selsk. Skr., Naturvidensk. Math. Afd., ser. 5, 2: 296. 1851 = Parietaria microphylla L., Syst. nat. ed. 10(2): 1308. 1759.

Ervas 4-40 cm alt., prostradas ou eretas. Ramos 0,5-5 mm diâm., 4-alados, suculentos, geralmente muito ramificados, glabros; cistólitos fusiformes conspícuos. Lâminas 1,5-10 ×1-5 mm, ovais a elípticas 
até suborbiculares, glabras; ápice rotundo, obtuso ou subagudo; base atenuada à aguda ou obtusa a rotunda; margem inteira; uninervia; cistólitos dispostos perpendicularmente à nervura, dando a lâmina um aspecto estriado; pecíolos até $4 \mathrm{~mm}$ compr, glabros; estípulas 0,5-1 mm compr. Inflorescências axilares, subsésseis ou até $2 \mathrm{~mm}$ pedunculadas, esparsamente ramificadas; brácteas 0,3-0,5 $\mathrm{mm}$ compr., hialinas. Inflorescências estaminada 0,5-4 mm compr., glomeruliforme, 4-5 flores, sésseis e subsésseis; flores estaminadas 0,3-0,5 mm compr., glabras; alvas; lóbulo giboso; estames dobrados no botão, deiscência explosiva. Inflorescências pistiladas 1-2 mm compr., cimeiras dicotômicas, 7-12 flores, pediceladas; flores pistiladas 0,1- 0,6 mm compr., lóbulo central cuculado, maior que os laterais; estigma séssil; ovário globoso. Aquênios 0,3-0,5 × 0,3-0,4 mm, ovais, ligeiramente achatados, curtamente pedicelados, castanhos.

Material examinado: 8-IV-2003, fl. Ô, F.C. Corrêa \& L. Mendonça 1 (SP); 27-I-1947, fl. +, O. Handro \& J.F. Toledo s.n. (SP49944).

Distribuição geográfica: Ocorre desde o México até a Argentina.

Pilea microphylla pode ser reconhecida pelo tamanho variável e forma difusa de seus ramos suculentos, possui folhas desiguais e de tamanho reduzido. Esta espécie é freqüentemente encontrada no interior da mata, áreas ajardinadas e adventícia em paredes e calçadas úmidas de áreas urbanas.

\section{Urera Gaudich.}

Arbustos dióicos, inermes ou armados; indumento de tricomas urticantes e acúleos presentes. Folhas alternas, espiraladas até dísticas. Lâminas inteiras, lisas ou rugosas, cartáceas ou membranáceas; estipulas axilares, livres ou conadas na base. Inflorescências em cimeiras dicotômicas ou irregularmente escorpióides, ou mais raramente em glomérulos; brácteas presentes; flores pediceladas ou sésseis; flores estaminadas 4-5-lobadas, lóbulos conados na base; prefloração valvar à levemente imbricada; estames 4-5, livres, filetes retos ou dobrados no botão; pistilódio presente com ovário rudimentar, glabro ou com tricomas simples concentrados na base. Flores pistiladas 4-lobadas, lóbulos desiguais, lóbulos centrais maiores que os laterais, conados na base; estigma penicilado terminal, persistente no fruto. Aquênios ovais ou arredondados, retos ou oblíquos, comprimidos ou convexos, lisos ou levemente rugosos, protegidos pelo perigônio acrescente, carnoso e colorido; pericarpo levemente crustáceo. Sementes elípticas ou ovais, testa membranácea; endosperma escasso; cotilédones ovais ou elípticos.

Urera inclui cerca de 40 espécies com distribuição tropical e subtropical, principalmente na África (Rooij 1975). Na região neotropical ocorrem cerca de 12 espécies, destas U.baccifera, U. caracasana, U. nitida e U. laciniata Goudot ex Wedd. ocorrem no Estado de São Paulo. Para o PEFI apenas U. laciniata não foi encontrada.

\section{Chave para a identificação de espécies de Urera ocorrentes no Parque Estadual das Fontes do Ipiranga}

1. Folhas ovais; base obtusa a (sub) cordada; face adaxial híspida; face abaxial opaca; inflorescências 6-20 cm, alaranjadas ou esverdeadas

2. Folhas com margem dentada; inflorescências 6-13 cm, alaranjadas U. baccifera

2. Folhas com margem crenada a serrilhada; inflorescências $15-20 \mathrm{~cm}$, esverdeadas ........... U. caracasana

1. Folhas lanceoladas; base aguda; face adaxial lisa; face abaxial brilhante; inflorescências 1-3 cm,

vináceas U. nitida

Urera baccifera (L.) Gaudich. ex Wedd., Ann. Sci. Nat. Bot., sér. 3. 18: 199. 1852 =Urtica baccifera L., Sp. pl. 2: 1398. 1753.

Figura 1k

Nome popular: urtiga-da-folha-grande, urtigão

Arbustos 3-4 m alt. Ramos 0,5-1 cm diâm., pubérulos a hirtelos, tricomas urticantes desde a base. Lâminas 14-28 × 11-20 cm, ovais, cartáceas; face adaxial rugosa, pubérula a hirtela, indumento de tricomas urticantes distribuídos em todo o limbo; face adaxial híspida; face abaxial opaca; cistólitos concentrados próximo às nervuras; ápice agudo a acuminado; base obtusa a (sub)cordada; margem dentada; 6-10 pares de nervuras secundárias; estípulas 0,5-2,5 cm compr., cuspidadas, caducas, pubérulas; 
pecíolos (4-)7-24 cm compr., estriados, pubérulos. Inflorescências axilares, 6-15 cm compr., alaranjadas, róseo-vináceas, pubescentes, assimétrica; brácteas interflorais 1-1,5 mm compr.; flores estaminadas 5-lobadas, sésseis ou (sub)sésseis; lóbulos 1-1,5mm compr.; estames 5; flores pistiladas 4-lobadas; lóbulos 0,3-0,5mm compr.; estigma globoso. Aquênios achatados, 3-4 mm diâm., assimétricos, rugosos, envolto por perianto carnoso acrescente, alvo na maturação. Sementes ovais, estriadas; cotilédones largos; embrião reto.

Material examinado: 8-XII-2007, fl. ô, S. Romaniuc Neto \& B.M.O. Guido 8380 (SP); 18-XII-2007, fl. O, S. Romaniuc Neto \& B.M.O. Guido 8387 (SP).

Distribuição geográfica: Ocorre desde a América Central até a Argentina, principalmente nas matas secundárias. Amplamente distribuída em todo o Estado de São Paulo em áreas abertas e bordas de matas.

$U$. baccifera pode ser reconhecida pelas inflorescências alaranjadas a róseo-vináceas, flores estaminadas 5-lobadas e aquênio achatado com tamanho pelo menos duas vezes maior que as demais espécies ocorrentes no PEFI.

Urera caracasana (Jacq.) Griseb., Fl. Brit. W. I. 154. 1859 =Urtica caracasana Jacq., Hort. Schoenbr. 3:71, t. 386. 1798 .

\section{Figura 11}

Arbustos 2-4 m alt. Ramos 0,5-0,7 mm diâm., suculentos, griseos, geralmente aculeados na base, inermes e pubescentes no ápice. Lâminas 10-15 $\times 6-12 \mathrm{~cm}$, ovais; face adaxial híspida a hirtela, indumento de tricoma simples; face abaxial estrigosa a velutina; tricomas urticantes em ambas as faces; ápice acuminado; base cordada ou arredondada; margem crenada a serrilhada; 5-6 pares de nervuras secundárias; cistólitos puntiformes distribuídos por todo o limbo; pecíolos 3-4 cm compr., hirtelos, estrigosos, pubescentes; estípulas $0,5-1,5 \mathrm{~cm}$ compr., persistentes ou caducas, bífidas, pubérulas. Inflorescências 10-20 cm compr., esverdeadas, pubérulas; brácteas interflorais de 0.5-1 $\mathrm{mm}$ compr, pubescentes; flores estaminadas 2-3 mm diâm., perianto globoso, lóbulos 1-1,5 mm compr.; estames exsertos na antese; pistilódio discóide; flores pistiladas 0,3-10 mm compr., solitárias ou em grupos de 3, livres, 4-lobadas, lóbulos 3-5 mm compr., desiguais, os internos mais largos que os externos; estigma séssil, persistente, capitado. Aquênios 1-1,5 mm diam., globosos, perianto carnoso acrescente, coloração alva na maturação. Sementes ovais, castanhas.

Material examinado: 14-III-1967, fl. ㅇ, T. Sendulsky 617 (SP).

Material adicional examinado: BRASIL. São Paulo: Ubatuba, 30-I-1996, fl. O, H.F. Leitão Filho et al. 34540 (SP); Bahia: Itaberaba, 18-I-2006, fl. ô, L.P. Queiroz 12076 (SP).

Distribuição geográfica: Desde o México até a Argentina, principalmente no interior da mata No Estado de São Paulo ocorre em áreas de matas mesófilas semidecíduas.

U. caracasana pode ser reconhecida pelos ramos carnosos, folhas cordadas com margem crenada a serrilhada, denso indumento velutino na face abaxial e pelo estigma capitado persistente no fruto.

Urera nitida (Vell.) Brack, Napaea 1: 7.1987 三Urtica nitida Vell., Fl. flum. 10: t. 20. 1825.

Figura $1 \mathrm{~m}$

Nome popular: urtiga, urtigão

Arbustos 0,8-3 m alt. Ramos 0,3-0,5 cm diâm., pubérulos, tricomas urticantes esparsos. Lâminas 6-22 × 2-9 cm, lanceoladas, membranáceas; face adaxial lisa, glabra; cistólitos concentrados próximo às nervuras; face adaxial lisa, brilhante, glabra, cistólitos distribuídos por todo o limbo; ápice agudo, acuminado; base aguda; margem inteira a esparsamente dentada; 6-10 pares de nervuras secundárias; estípulas 5-7 mm compr., triangulares, bífidas, conadas, caducas, pubérulas; pecíolos (2-)5-15 cm compr., estriados, glabros. Inflorescências axilares, 1-3 cm compr., vináceas, assimétrica, pubescente, indumento de tricomas urticantes; brácteas interflorais 5-8 mm compr.; flores estaminadas 4-5-lobadas, sésseis ou (sub) sésseis; lóbulos 1-1,5 mm; estames 5. Flores pistiladas 4-lobadas, lóbulos 0,5-0,8 mm; estigma penicilado. Aquênios oval-arredondados, 2-3 mm diâm., simétricos, rugosos, envolto por perianto carnoso acrescente, rósea a castanho-alaranjado na maturação. Sementes ovais, estriadas; cotilédones elípticos; embrião reto.

Material examinado: 8-IV-2003, fl. , F.C. Corrêa \& L. Mendonça 2 (SP).

Material adicional examinado: BRASIL. São Paulo: São Sebastião, 26-III-1892, fl. Ô, G. Edwall 1726 (SP); Ubatuba, 11-XI-1993, fl. O̊, A.C.E. Pontel et al. 29800 (SP). 

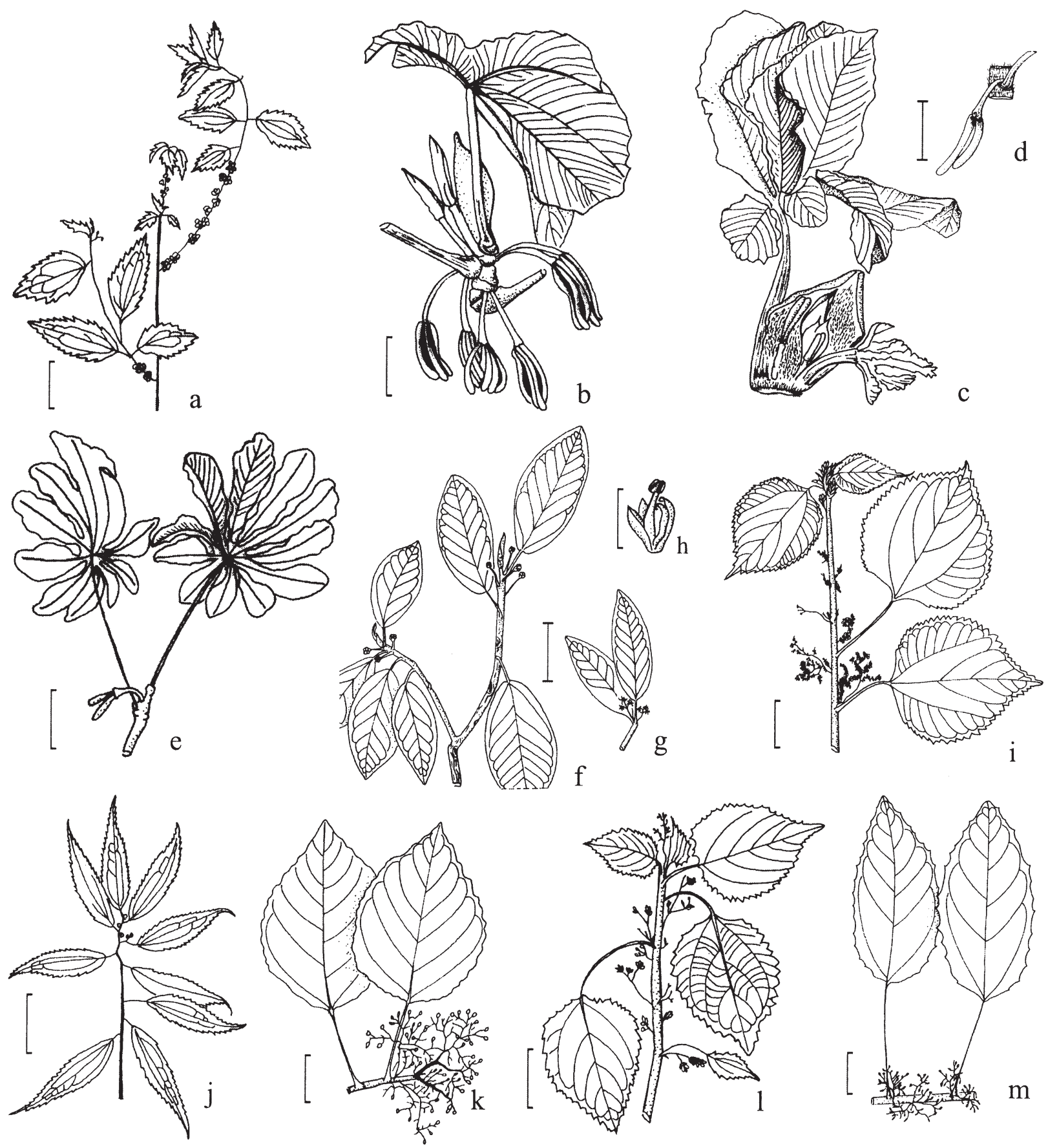

Figura 1. Boehmeria cylindrica. a. Hábito (G. Eiten \& W.D. Cleyton 5791). Cecropia glaziovii. b. hábito (S. Romaniuc Neto 760). c-d. Cecropia hololeuca. c. Hábito. d. Inflorescência pistilada. (S. Romaniuc Neto 761). Cecropia pachystachya. e. Hábito. (S. Romaniuc Neto 1512). f-h. Coussapoa microcarpa. f. Hábito (M. Kuhlmann 2837). g. Ramo com inflorescências estaminada. h. Flor estaminada. (I. Cordeiro \& C. Vilela 1237). Laportea aestuans. i. Hábito. (T. Sendulsky 650). Phenax sonneratii. j. Hábito. (T. Sendulsky 652). Urera baccifera. k. Hábito. (S. Romaniuc Neto \& B. M. O. Guido). Urera caracasana.1. Hábito. (T. Sendulsky 617). Urera nitida. m. Hábito. (F. C. Corrêa \& L. Mendonça 2)

Figure 1. Boehmeria cylindrica. a. Habit (G. Eiten \& W.D. Cleyton 5791). Cecropia glaziovii. b. Habit (S. Romaniuc Neto 760). c-d. Cecropia hololeuca. c. Habit. d. Pistillate inflorescence. (S. Romaniuc Neto 761). Cecropia pachystachya. e. Habit. (S. Romaniuc Neto 1512). f-h. Coussapoa microcarpa. f. Habit (M. Kuhlmann 2837). g. Leafy twig with staminate inflorescence. h. Staminate flower. (I. Cordeiro \& C. Vilela 1237). Laportea aestuans. i. Habit. (T. Sendulsky 650). Phenax sonneratii. j. Habit. (T. Sendulsky 652). Urera baccifera. k. Habit. (S. Romaniuc Neto \& B. M. O. Guido). Urera caracasana.1. Habit. (T. Sendulsky 617). Urera nitida. m. Habit. (F. C. Corrêa \& L. Mendonça 2) 
Distribuição geográfica: Ocorre ao longo da região litorânea do Brasil desde Pernambuco até Rio Grande do Sul (Brack, 1987). Amplamente distribuída principalmente no centro e sul do Estado de São Paulo.

U. nitida (Vell.) Brack é geralmente confundida com $U$. baccifera, diferindo desta principalmente pela forma, textura e indumento das lâminas foliares. No PEFI $U$. nitida é frequente no interior da mata, diferentemente de $U$. baccifera que ocorre na borda da mata e em locais abertos e ajardinados.

\section{Literatura citada}

APG II (Angiosperm Phylogeny Group). 2003. An update of the Angiosperm Phylogeny Group classification for the orders and families of flowering plants: APG II. Botanical Journal of the Linnean Society 141: 399-436.

Barros, F., Mamede, M.C.H., Melo, M.M.F., Lopes, E.A., Jung-Mendaçolli, S.L., Kirizawa, M., Muniz, C.F.S., Watanabe, H.M., Chiea, S.A.C. \& Melhem, T.S. 2002. A flora fanerogâmica do PEFI: composição, afinidades e conservação. In: D.C. Bicudo, M.C. Forti \& C.E.M. Bicudo (orgs.). Parque Estadual das Fontes do Ipiranga (PEFI): unidade de conservação que resiste à urbanização de São Paulo. Secretaria do Meio Ambiente do Estado de São Paulo, São Paulo, pp. 93-110.

Berg, C.C. 1978. Cecropiaceae, a new family of the Urticales. Taxon 27:39-44.

Berg, C.C. 1992. Urticaceae. In: A.R.A. Gorts-van Rijn (ed.). Flora of the Guianas, sér. A, 23: 125-139.

Berg, C.C. \& Carauta, J.P.P. 1996. Cecropia (Cecropiaceae) no Brasil, ao Sul da Bacia Amazônica. Albertoa 4: 216-221.

Berg, C.C. \& Rosselli, F.P. 2005. Cecropia. Flora Neotropica Monograph 94. The New York Botanical Garden, New York.

Bicudo, D.C., Forti, M.C. \& Bicudo, C.E.M. (orgs.). 2002. Parque Estadual das Fontes do Ipiranga (PEFI): unidade de conservação que resiste à urbanização de São Paulo. Secretaria do Meio Ambiente do Estado de São Paulo, São Paulo.

Brack, P. 1987. O Gênero Urera (Urticaceae) no Rio Grande do Sul, Brasil. Napaea 1: 1-11.

Burger, W.C. 1977. Flora Costaricensis. Family 53 Urticaceae. Fieldiana, Botany 40: 218-283.

Carauta, J.P.P. 1996. Moráceas do Estado do Rio de Janeiro. Albertoa 4: 145-194.

Carauta, J.P.P., Romaniuc Neto, S. \& Sastre, C. 1996. Índice das espécies de Moráceas do Brasil. Albertoa 7: 78-93.
Chew, W.L. 1965. Laportea and allied genera (Urticaceae). Gardens Bulletin of Singapore 21: 195-208.

Chew ,W.L. 1969. A monograph of Laportea (Urticaceae). Gardens Bulletin of Singapore 25: 111-178.

Cronquist, A. 1988. The evolution and classification of the flowering plants. 2 ed. New York Botanical Garden, New York.

Fidalgo, O.\& Bononi, V.L.R. (coords.). 1984. Técnicas de coleta, preservação e herborização de material botânico. Instituto de Botânica, São Paulo.

Hoehne, F.C., Kuhlmann, M. \& Handro, O. 1941. O Jardim Botânico de São Paulo. Secretaria da Agricultura, Indústria e Comércio, Departamento de Botânica do Estado, São Paulo.

Judd W.S., Sanders R.W. \& Donoghue M.J. 1994. Angiosperm family pairs: preliminary phylogenetic analyses. Harvard Papers in Botany 5: 24-30.

Judd W.S., Campbell, C.S., Kellogg, C.A. \& Stevens, P.F. 1999. Plant Systematics, a phylogenetic approach. Sianuer Associates, Sunderland.

Killip,E.P. 1960. Flora of Panama (Urticaceae). Annals of the Missouri Botanical Garden 47: 179-198.

Melhem, T.S., Giulietti, A.M., Forero, E., Barroso, G.M., Silvestre, M.S.F., Jung, S.L., Makino, H., Melo, M.M.R.F., Chiea, S.C., Wanderley, M.G.L., Kirizawa, M. \& Muniz, C. 1981. Planejamento para elaboração da "Flora Fanerogâmica da Reserva do Parque Fontes do Ipiranga (São Paulo, Brasil)". Hoehnea 9: 63-74.

Milanez, A.I., Bicudo, C.E.M., Vidal, D.M. \& Grandi, R.A.P. 1990. Criptógamos do Parque Estadual das Fontes do Ipiranga, São Paulo, SP: Planejamento. Hoehnea 17: 43-49.

Miquel, F.A.W. 1853. Urticineae: Urticeae. In: C.F.P. von Martius (ed.), Flora Brasiliensis. Typographia Regia, Monachii, v. 4, pt.1, pp. 184-206.

Monro, A.K. 2001. Synopsis of Mesoamerican Pilea including eighteen typifications and a Key to the species. Bulletin of the Natural History Museum, Botany series 31: 9-25.

Rocha, Y.T. \& Cavalheiro, F. 2001. Aspectos históricos do Jardim Botânico de São Paulo. Revista Brasileira de Botânica 24: 577-586.

Romaniuc Neto, S. 1992. Urticaceae. In: M.M.R.F. Melo, F. Barros, S.A.C. Chiea, M. Kirizawa, S.L. Jung-Mendaçolli \& M.G.L. Wanderley (eds.). Flora Fanerogâmica da Ilha do Cardoso 3: 161-165.

Romaniuc Neto, S. 1993. Flora Fanerogâmica da Reserva do Parque Estadual das Fontes do Ipiranga (São Paulo, Brasil). 19A - Cecropiaceae. Hoehnea 20: 129-132.

Romaniuc Neto, S. 1999. Cecropioideae (C.C. Berg) Romaniuc Neto stat. nov. (Moraceae-Urticales). Albertoa, nova série 4: 13-16. 
Rooij, M.J.M. 1975. Urticaceae. In: J. Lanjouw \& A.L. Stoffers (eds.). Flora of Suriname 5(1): 300-318.

Soraru, S.B. 1972. Revision de las Urticaceae de Argentina. Darwiniana 17: 246-325.

Sytsma, K.J., Morawetz, J., Pires, J.C., Nepokroeff, M., Conti, E., Zjhra, M., Hall, J.C. \& Chase, M.W.
2002. Urticalean rosids: circunscription, rosid ancestry, and phylogenetics based on rbcL, trnL-F, and ndhF sequences. American Journal of Botany 89: 1531-1546.

Weddell, H.A. 1856-1857. Monographie de la famille des Urticacées. Archives du Museum d'Histoire Naturelle, Paris 9: 401-591. 